\title{
Turkey: A Neglected Partner
}

\author{
Paul A. Williams
}

\begin{abstract}
$\mathrm{W}_{\mathrm{i}}$ ith the main focus of Barack H. Obama's first foreign tour on multinational summitry (including the G20 summit in London and the North Atlantic Treaty Organization [NATO] meeting in Strasbourg), capping his itinerary with a visit to Turkey seemed incongruous. After affirming in his April speech before Turkey's parliament, known as the Grand National Assembly, that he had chosen Turkey "to send a message to the world" and then enumerating key global issues, Obama remarked, "No one nation can confront these challenges alone, and all nations have a stake in overcoming them....We are stronger when we act together." ${ }^{\prime}$ Yet this speech did not serve merely to differentiate Obama's approach from the preceding administration's reputation for unilateralism and "bring-it-on" confrontationalism. Although this renown was largely earned by U.S.-led interventions in Afghanistan and Iraq, Obama could have demonstrated his opposing policy sensibility anywhere other than in a Muslim-majority country.

Significantly, he selected a country - the site of one of the longestrunning and most successful national experiments (albeit periodically fraught with illiberal reversals) in the often-unstable alchemy of secularism, democracy, and Islam-in which he could highlight a wider range of policy departures and personal attributes with particular relevance to the Middle East. His speech alluded to the perceived failure of Bush's Broader Middle East and North Africa (BMENA) democracy-promotion initiative: “Turkey's democracy is your own achievement. It was not forced upon you by any outside power, nor did it come without struggle and sacrifice." ${ }^{2}$ However, the signature impact of Obama's speech probably derives from the following statement:
\end{abstract}

The United States is not ... at war with Islam.... America's relationship with...the Muslim world, cannot...just be based upon opposition 
to terrorism. We seek broader engagement based on mutual interest and mutual respect....We will convey our deep appreciation for the Islamic faith, which has done so much over the centuries to shape the world-including in my own country. The United States has been enriched by Muslim Americans. Many other Americans have Muslims in their families or have lived in a Muslim-majority country-I know, because I am one of them. ${ }^{3}$

Despite the prescient assertion by a former U.S. ambassador to Turkey that the "next U.S. President will get a bounce in terms of Turkish public opinion just by not being George W. Bush,"4 this beau geste did not obviate Obama's need to tread carefully on specific issues that have vexed Turco-U.S. relations, independently of whoever occupies the White House and however America may stand in terms of broader Muslim public opinion. The 2003 U.S.-led invasion of Iraq was never popular in Turkey, as manifested in a final-hour failure of its newly elected ruling majority Justice and Development Party (JDP) to muster a sufficient parliamentary majority on March 1 of that year to permit 62,000 U.S. forces to cross Turkey. Opposition stemmed as much from aversion in Turkey to the war's potentially negative consequences on its direct interests as from widespread revulsion at an attack by a non-Muslim country on a predominantly Muslim one (after all, Turkish forces have participated in and even headed NATO's International Security Assistance Force in post-2001 Afghanistan). ${ }^{5}$ Turkey had already borne heavy economic losses stemming from post-Gulf War UN sanctions on Saddam Hussein's regime and anticipated more to come. Turks also feared that the occupation would confer autonomy on the predominantly Kurdish population of northern Iraq and hinder Turkey's fight against armed separatists of the Kurdish Workers Party (PKK), which had established bases in that part of Iraq to launch terror attacks in Turkey.

Another major issue has perturbed U.S. policy toward Turkey. Groups claiming to represent the Armenian diaspora-most notably descendants of people who fled the so-called 1915 "genocide" by Ottoman forces against Armenian inhabitants of lands in modernday Turkey-have waged a steady campaign since the 1970s to secure formal U.S. congressional recognition (already granted by some European governmental bodies) that up to 1.5 million Armenians were systematically killed by Ottoman forces. Turkey fears that recognition would open the floodgates to claims for compensation and territorial restitution. ${ }^{6}$ Thus, to the extent that they need Turkey's cooperation, U.S. presidents have hewed to a pro-Turkey line on these issues, dovetailing with their efforts to limit the intrusion of human 
rights agendas (a prioritization that often distances the United States from the EU).

Indeed, U.S. presidents have continued to oppose congressional "Armenian genocide" resolutions, with this recurring decision having become undergirded as much by concurrent efforts of the "Jewish lobby" to cultivate a Turco-Israeli alliance (under severe strain in 2009-2010) as by Turkey's general geostrategic significance. Despite post-cold war U.S. presidential backing for Turkey's anti-PKK struggle, its "alliance" with Israel, a larger trans-Turkish corridor for Caspian and Middle East energy supplies, and Turkey's EU membership bid, the United States remained highly unpopular in Turkish public opinion during the first decade of the third millennium. Turkey's ingrained anti-Americanism has been compounded by declining EU popularity there (over partial suspension of accession talks that had opened only in late 2005) and tension between the JDP government and Israel over the latter's embargo on Gaza that escalated after the Israeli Defense Forces (IDF) killed eight Turks on a flotilla ship that sought to breach the embargo in late May 2010. Already working within certain parameters on its Turkey policies set by the cumulative effect of past U.S. legislative and executive decisions, the Obama administration may-despite its overtures toward Turkey as a "model partner"7-become less conciliatory on issues of concern to Turkey. After surveying the cold war tableau of this bilateral relationship, this chapter turns to the post-cold war fixtures of U.S. policy toward Turkey with which Obama has had to work, as well as to the broader changes in Turkish domestic and foreign policy with which he has had to reckon.

\section{Cold War Turco-U.S. Relations}

From a distance, the luster of the postwar Turco-U.S. relationship-one indelibly shaped by the 1947 Truman Doctrine proclamation, Turkish troops' decorated combat service in the Korean War, and Turkey's landmark 1952 NATO admission-appears undiminished, although closer scrutiny of the tableau reveals inherent tensions between its various elements, rends in the fabric, and some hasty restorations to highlight the two parties' "alliance" scenery. This tapestry forms a background for understanding subsequent U.S. policy toward Turkey.

U.S. power was at its most hegemonic from the late 1940s to the early 1960s. This coincides with an aptly named "honeymoon period" of Turco-U.S. relations. ${ }^{8}$ This era began with the 1947 Truman Doctrine address, which called for $\$ 400$ million in aid, as 
well as deployment of U.S. civilian and military personnel, to defend Greece and Turkey (which received one quarter of that assistance) from Soviet-backed incursions. The period continued with the 1948 European Recovery Act (i.e., Marshall Plan), which included an Economic Assistance Program for Turkey. By the late 1950s, the U.S. "domination role" 9 had been attenuated by the development of a Soviet nuclear retaliatory capacity and by West Europe's economic recovery, symbolized by the 1957 founding of the European Economic Community (EEC).

Turkey was highly dependant on U.S. foreign aid in this period. During 1946-1965, it received $\$ 4.315$ billion in official U.S. grants and credits. ${ }^{10}$ This suggests a profoundly asymmetrical relationship favoring U.S. interests, one that accords with neorealist International Relations (IR) theory's expectation of the ties between a superpower and its allies in a bipolar world. ${ }^{11}$ However, the practical workings of the postwar Turco-U.S. relationship were circumscribed at the outset by salient regard for Turkey's sovereignty and national pride. Early on, the U.S. ambassador was designated "chief of mission" in lieu of "administrator" (of Marshall Plan aid), and military branch heads designated "directors," in deference to "bitter memories of the history of capitulations in Turkey." 12 Within the respective frameworks of the 1949 and 1951 treaties creating NATO and its Status of Forces arrangements (SOFA), U.S. military bases, personnel, and operations in Turkey fell under concurrent jurisdiction according to the 1954 SOFA. Even the 1959 arrangement providing Turkey with 15 Jupiter intermediate range ballistic missiles (IRBMs) was a "cumbersome" mix involving Turkish ownership of the missiles, U.S. ownership and custody of their nuclear warheads, and joint launch authority. ${ }^{13}$ Indeed, these missiles became contentious three years later, partly out of U.S. concern that trading them off for Soviet missiles in Cuba would offend Ankara. ${ }^{14}$ The 1964 Soviet disclosure of a U.S.-Soviet bargain over the Jupiters became grist for Turkish leftist opposition to the U.S. military presence and later for official resistance to joining NATO's Multilateral Nuclear Strike Force (which Turkey had agreed to do in 1963). ${ }^{15}$

The security-oriented nature and elitist conduct of Turco-U.S. relations unsurprisingly made the U.S. military in Turkey a target of protest and violence starting in the 1960s. Even the "honeymoon" featured disputes over U.S. use of Turkish bases, namely during the 1957 Lebanon crisis and the May 1960 crisis over the downing of Gary Powers's U2 spy plane. ${ }^{16}$ However, rising intercommunal tensions in 1963-1964 between the Greek and Turkish communities 
on Cyprus (a crisis that flared up again in 1974 and resulted in congressional imposition of the 1975-1978 U.S. arms embargo against Turkey) and President Lyndon B. Johnson's June 1964 “letter" admonishing Turkey not to use U.S. weapons in defense of Turkish Cypriots nor to expect NATO backing in the event of Soviet counterintervention marked the start of a 16-year souring of relations that has been termed "years of digression." 17 As Nur Bilge Criss states, "The Johnson letter was a turning point in the Turkish shift toward a multidimensional foreign policy," 18 which the foreign minister Ahmet Davutoglu turned into an explicit operating principle of the JDP government's foreign policy. ${ }^{19}$

During this time, U.S. presidents tried to preserve the relationship. U.S. aid to Turkey did fall from \$3.020 billion, over the 1956-1965 heyday of Turkish participation in the U.S.-backed Central Treaty Organization (CENTO), to $\$ 2.703$ billion during the 1966-1974 period. $^{20}$ The $1975-1978$ congressional ban on arms transfers to Turkey severely curtailed military aid (to about $\$ 134$ million per annum during those years, nearly the same as during the Truman years). ${ }^{21}$ Even before the embargo, which provoked Turkey's abrogation of the 1969 Mutual Defense Cooperation Agreement and seizure of control over all joint military installations, Ankara had already begun to demonstrate a greater proclivity to object to perceived U.S. SOFA infringements and to distance itself from U.S. positions. ${ }^{22}$ This deviation in Turkish foreign policy interacted both with U.S. policy changes (stemming not only from Cyprus-related events but also from Nixon's pressure on Turkey to eradicate its poppy production) and the flourishing of radical extremists (mirrored by their counterparts in the tenuous multiparty parliamentary coalitions), who battled each other and terrorized foreign diplomatic and military personnel. ${ }^{23}$ Political violence and the widening gulf between respective foreignpolicy priorities slowed considerably after the September 1980 coup and the consequent sweeping changes that were implemented in the Turkish political and economic systems.

\section{Post-Cold War U.S. POLICY TOWARD TURKEY}

Pre-1964 postwar relations proceeded, relatively speaking, down easy street, whereas the post-1964 relationship lurched onto a rocky road that was partially repaired in 1980 . However, as the cold war defined a common enemy to be contained, the greater uncertainty and mismatch of interests of the post-cold war era propelled Turco-U.S. 
relations into uncharted territory. Four U.S. presidents have had to navigate a realm of U.S. foreign policy that has been shaped as much by changes in Turkish public opinion as by the cumulative impact of their own and their predecessors' decisions.

\title{
“Multilateral Father": George H. W. Bush's Landmark-Event Turkey Policy
}

One issue that began to preoccupy Turco-U.S. relations started just before the formal end of the cold war (as the Soviet Union was still officially in business at this time) and centered on Iraq. Perhaps no Turkish leader other than Turkish Republic founder Mustafa Kemal Ataturk or 1960 coup-deposed Adnan Menderes garnered as much U.S. acclaim as President Turgut Ozal. Ozal bucked the strongly negative tide of Turkish public opinion and agreed to throw material support behind Operations Desert Shield (late 1990) and Desert Storm (early 1991), two halves of a campaign spearheaded by President George H. W. Bush to oust Saddam Hussein from Kuwait. These included the economic pinch (for Turkey as well as Iraq) of UN sanctions that continued to be imposed in some form or another until the full-scale March 2003 invasion of that country and deposing of the latter leader. ${ }^{24}$ Under Ozal,

\begin{abstract}
Ankara granted access and overflight rights to US combat aircraft operating from Incirlik Air Base and elsewhere in Turkey; deployed more than 100,000 troops along the Iraqi border to pin down substantial Iraqi forces; shut down its pipelines, cutting off Iraqi oil exports; and, after the conclusion of the war, allowed allied aircraft to fly sorties out of Incirlik to monitor the no-fly zone over northern Iraq. This signaled a dramatic shift in Turkish foreign policy, characterized until then by regional noninterference and minimization of foreign tensions for the sake of domestic stability. ${ }^{25}$
\end{abstract}

Turgut Ozal's risk taking did not occur in an international vacuum. If George W. Bush's decision to launch a near-unilateral invasion and occupation of Iraq in March 2003 represents a notable departure from the prevailing post-cold war pattern of U.S. presidencies adopting multilateral approaches to matters of coercive diplomacy and war, cultivation of Ozal's support by his own father's administration embodies the latter pattern. As one former U.S. ambassador to Turkey has written, "If diplomacy counts, it should be noted that before the [Gulf] war began Secretary of State James Baker visited 
Turkey three times to win Turkish support-three times more than any cabinet official prior to the 'second' Iraq war."26

\section{Bill Clinton and the "Enhanced Partnership"}

The 42nd presidency of William J. Clinton inherited the "enhanced partnership" established by the mutually effective and timely exercise of personal leadership by his predecessor and Turgut Ozal. Clinton perpetuated two unpopular policies in Turkey: UN sanctions against Saddam Hussein's regime (the costs of which fell disproportionately on both Iraq and Turkey) and the use of Incirlik Airbase-contingent on the Turkish parliament's biannual renewal of permission-to enforce the U.S./U.K. no-fly zone in northern Iraq. UN sanctions loosened over Clinton's two terms in office. The first phase of relaxation, which conceded to the reality of truck-borne oil smuggling via Jordan and Turkey, saw the December 1996 reopening of Iraq's Persian Gulf oil terminals and the Kirkuk-Yumurtalik (Iraq-Turkey) pipeline, mandated by UN Resolution 986 to transport the larger bulk of Iraq's oil exports. ${ }^{27}$

Although Turks chafed at the costs associated with UN sanctions, their larger security fears revolved around the existence of the no-fly zones. With new bases created in the northern zone, the PKK (later KADEK and, in its post-Iraq War incarnation, Kongra-Gel) continued attacks against Turkish targets in a campaign originally launched in 1984 from Lebanon's then Syrian-controlled Bekaa Valley. That campaign was backed by the Hafez al-Assad regime to try to stop construction on the major Euphrates River dams and irrigation schemes in Turkey's Southeast Anatolia Project. ${ }^{28}$ By the late 1990s, Syrian support for the PKK had almost single-handedly catalyzed a Turco-Israeli military alliance, put both Syria and the PKK on the State Department's new terrorism watch list, led Turkey to the brink of invading Syria in 1998, and prompted U.S. and Israeli intelligence to assist in capturing PKK head Abdullah "Apo" Ocalan in 1999.

In a preview of Obama's style, Bill Clinton endeavored to impart new substance to the "enhanced partnership." Harnessing an "initial wave" of post-cold war activism in Turkish foreign policy, ${ }^{29}$ Clinton sought Ankara's assistance for humanitarian operations in Somalia, Bosnia, and Kosovo. ${ }^{30}$ Responding to the poor economic circumstances in which he took office, Clinton also emphasized stronger trade ties. Although Clinton-era figures are dwarfed by percentage increases in bilateral trade between the respective final years in office 
of Presidents Jimmy Carter and Ronald Reagan and reflect an overall expansion of U.S. trade (which also applies for U.S. foreign direct investment [FDI]), total dollar volume of bilateral trade between 1992 and 2000 rose by nearly three quarters, with the volume of Turkish exports to the United States nearly trebling in value. ${ }^{31}$ Following his well-received visit to Turkey after the 1999 earthquakes in Izmit and Duzce, Clinton-who mingled with inhabitants of a makeshift tent city-also pledged \$1 billion in Exim Bank loans and facilitated a major three-year IMF (International Monetary Fund) standby loan to Turkey (initially approved at SDR 2.892 billion in December 1999 but trebled just before he left office). ${ }^{32}$

Clinton combined commercial and geopolitical objectives in a way that largely dovetailed with Turkey's interests. As part of its overall policy of promoting economic independence, democracy, and market openness in the former Soviet Union (FSU), the Clinton administration advocated "multiple pipelines" extending from the hydrocarbonrich Caspian Sea littoral states to Turkey. Although Russia was not explicitly excluded from any new energy "corridor"-indeed, Soviet monopolization of all routes of egress for oil and gas exports from the present Caspian states of Azerbaijan, Kazakhstan, Turkmenistan, and Uzbekistan made any exclusion nearly impossible-Iranian routes were expressly precluded. ${ }^{33}$ The prohibition on Iran's inclusion in U.S.-sponsored energy routes, one adhered to by George W. Bush and Barack Obama, originated in Clinton's 1995 executive order banning U.S. trade and investment in Iran (an order that has been renewed every March since then) and his approval of the 1996 Iran and Libya Sanctions Act (ILSA-ISA since 2006), which generalized this ban to foreign firms investing \$20 million or more per year in Iran. ${ }^{34}$

Iran sanctions proved a mixed blessing for Turkey. As symbolized by Clinton's presence alongside the Turkish president Suleyman Demirel at the signing of some energy agreements during his aforementioned visit to Turkey, the United States extended an immense geopolitical "lifeline" to the Baku-Tbilisi-Ceyhan (BTC) crude oil pipeline, the commercial prospects of which were inauspicious in the 1990s. ${ }^{35}$ However, by similarly enfeebling Iran's capacity to produce and transport natural gas westward, they potentially undercut the feasibility of the mammoth Nabucco Pipeline project, an undertaking backed by both George W. Bush and Barack Obama as well as the European Commission to transport up to 31 billion cubic meters of gas per year through Turkey from potential supplier countries Azerbaijan, Egypt, Iran, Iraq, and Turkmenistan. ${ }^{36}$ Sanctions also directly clashed with Turkey's plans to import Iranian gas dating 
back to a 1997 agreement worth $\$ 19$ billion. ${ }^{37}$ Given that Turkish firms planned to work only on Turkey's section of the current TabrizErzurum pipeline, the U.S. State Department demurred on the applicability of ILSA sanctions, arguing, "Turkey would be importing gas originating in Turkmenistan, not Iran, under a swap arrangement." 38 This matter continues to circumscribe Turco-U.S. cooperation on the "east-west transportation corridor."

Clinton also faced the dilemma of justifying the suppression of congressional resolutions condemning Turkey on human-rights grounds while also promoting its EU membership. Notably, though not the first U.S. president to oppose legislation embodying views that he personally shared, Clinton pressured the House in 2000, just as his predecessor had done in 1990 vis-à-vis the Senate, to withdraw a nonbinding resolution recognizing the Armenian "genocide." 39 Although the EU rebuffed Turkey at Luxembourg in 1997, it reversed its stance at Helsinki in 1999, partly because of Clinton's support for Turkey's bid. Still, the EU's traditionally insular orientation, the higher premium it attaches to member states' democratic credentials relative to their military prowess, and its abiding focus on the costs of admitting Turkey (an area where the U.S. can enjoy a "free ride") have restricted the extent to which any U.S. administrations can accelerate Turkey's admission. ${ }^{40}$

\section{"Unilateral Son": Rupture of the "Strategic Relationship" under George W. Bush}

Ironically, it was this administration's officials, whose policies played a large role in bringing Turco-U.S. relations to new lows of discord, who stepped up pressure on the EU to admit Turkey. This campaign occurred in the run-up to the EU's December 2002 Copenhagen summit but largely because the U.S. administration, already planning to invade Iraq, had an instrumental interest in using Turkey for the passage of U.S. troops. This put an even more pronounced stress on the security-oriented nature of U.S. concerns for Turkey's EU bid. ${ }^{41}$ Despite haggling that yielded Turkey $\$ 15$ billion in aid (one-third in cash and the remainder in loan guarantees), the late February 2003 deadlock in the UNSC on approving a U.S.- and U.K.-proposed second resolution authorizing intervention in Iraq, combined with months of mutual diplomatic ineptitude, created circumstances wherein the March 1, 2003, Turkish Grand National Assembly vote to allow use of its territory for that purpose lacked a sufficient majority. ${ }^{42}$ 
This vote and the security ramifications for Turkey of losing much of its ability to shape the nature of the U.S.-led occupation of Iraq significantly worsened bilateral ties. The period between March 2003 and November 2007-when the United States began providing "actionable" satellite intelligence to the Turkish military to fight the PKK- "marked the lowest point in relations since the U.S. arms embargo of 1975-78," with "reservoirs of trust on both sides ... greatly depleted." ${ }^{43}$ Despite Turkey's last-minute approval of American use of Incirlik Airbase for the Iraq war effort, the war's immediate aftermath saw the abrogation of the U.S. assistance package and warnings to Turkey (echoed by the European Commission) to refrain from intervening in northern Iraq, where defense of the ethnic Turcoman minority offered a potential pretext. ${ }^{44}$ In the context of this rupture, the U.S. capture and "hooding" on July 4, 2003, of 11 Turkish covert special-forces operatives in the northern Iraq town of Sulaymaniyya (who were allegedly collaborating with the Turkmen Front) brought anti-American sentiments to an unprecedented pitch of virulence. ${ }^{45}$

Both parties were slow to repair this rend. In October 2003, Turkey begrudgingly authorized troops for Iraq, but the provisional Iraqi authority rejected them. ${ }^{46}$ The Bush administration dilatorily resumed U.S. advocacy of Turkey's EU accession bid, which included a parallel effort begun under Clinton to promote a Cyprus settlement, but this lobbying did not become salient until after Greek Cypriot rejection of the "Annan Plan" (endorsed by Turkish Cypriots) and Cyprus's subsequent EU accession in May 2004. ${ }^{47}$ The lingering trans-Atlantic rift over Iraq that saw Turkey aligning with France and Germany and moving to adopt EU-mandated reforms may have obviated the necessity of U.S. lobbying anyway. ${ }^{48}$ Largely forced by the massing of Turkish troops on the Iraq border and the need to keep trans-Turkey supply lines open, Bush's late-2007 decision to provide real-time intelligence on PKK movements in northern Iraq and to largely condone resulting Turkish military airstrikes, as well as the opening of a joint Office of Defense Cooperation in Ankara, nudged up levels of trust. ${ }^{49}$

\section{Barack Obama and the "Model Partnership"?}

For reasons of both necessity and personal style, Barack Obama's foreign policymaking embodied a renewed emphasis on multilateralism and a substantively differentiated approach to the Muslim world, as epitomized in his April 2009 speech in Turkey. In contrast to Bush's 
2004 visit, strongly symbolized by an expansive security cordon, Obama took part in a student roundtable. ${ }^{50} \mathrm{He}$ also elevated the importance of expanding commercial ties. ${ }^{51}$ Nonetheless, Obama (largely focused on economic recovery) found his administration mostly responding to, rather than actively influencing, new departures in Turkish foreign policy. Whereas some of these are positive from a U.S. standpoint, the negative ones may constrain the Obama administration's behavior or motivate it to act less conciliatorily toward Turkey.

President Obama has largely hewed to specific U.S. policy tacks on Turkey set by his predecessors. His administration continued to advocate on behalf of Turkey's EU bid, championed by the European Commission but notably opposed by France, which prefers restricting the EU to a "privileged partnership" with Turkey that the latter eschews. ${ }^{52}$ Even while supporting a brief interlude of "democratic opening" that the JDP government sought to initiate vis-à-vis Turkey's Kurdish population, Obama also pledged to maintain George H. W. Bush's second-term efforts to assist the Turkish military in prosecuting its post-2007 campaign to eradicate PKK camps in northern Iraq's Kandil mountain range. Moreover, he followed Clinton's policy of promoting Turkey as the hub of a new "East-West energy corridor," both reaffirming U.S. support for this vision during his Ankara visit and sending the U.S. special envoy for energy Richard Morningstar (who reprised his analogous role under Clinton) to attend the July 2009 Ankara signing ceremony of the Nabucco Project intergovernmental agreement by consortium states Austria, Bulgaria, Hungary, Romania, and Turkey. ${ }^{53}$

This latter project has faced an array of obstacles, including one generated by U.S. pressure on Turkey to normalize relations with Armenia, a process launched with a September 2008 World Cup qualifying match in Yerevan between Armenian and Turkish national teams, which was attended by both countries' presidents. This yielded a "road map" just before Obama was to make a ritual April 24 commemorative speech on the events of $1915 .{ }^{54}$ However, the process offended Turkey's traditional ally Azerbaijan, a major supplier of the BTC oil and Baku-Tbilisi-Erzurum (South Caucasus) gas pipelines (as well as the future Nabucco project) and one locked in conflict with Armenia over the latter's occupation of the Nagorno-Karabakh Province. Azeri leaders, already disputing Ankara on gas prices and transit fees, did not attend a related Istanbul summit meeting during Obama's visit and thereafter arranged to sell gas to Russia by $2010 .{ }^{55}$ The flagging of mutual political will for normalization made the 
political climate conducive to renewed Turco-Azeri gas agreements by mid-2010. ${ }^{56}$

Although this keeps U.S. policy consistent with support for the East-West transportation corridor, new trends in Turkish foreign policy under the JDP government may have diminished Obama's ability or will to safeguard against future U.S. congressional recognition of the Armenian "genocide." As the difficulty of reconciling AzeriArmenian relations hinted, the Turkish foreign minister Davutoglu's "vision-based" strategy—including "zero problems" with neighbors, policy multidimensionality, and diplomatic flexibility ${ }^{57}$ - ran into the highly intractable disputes in Turkey's environs. Whereas Obama expected Turkey, as Clinton did, to mediate in Israel's peace talks with the Palestinians and Syria and possibly between the United States and Iran as well as to continue its peacekeeping role in Lebanon and Afghanistan, the JDP government seems to have improved TurcoArab and Turco-Iranian relations at the expense of close post-1996 ties with Israel.

The anti-Israel posture of the JDP government did not readily appear when it first took power in 2002. It did become clearer in Davutoglu's early 2006 and 2009 visits with the Hamas representative Khaled Mashal; and it was more overtly manifest in the Turkish prime minister Recep Tayyip Erdogan's public tirade and walk-off at the 2009 World Economic Forum against the Israeli president Shimon Peres over Israel's deadly military offensive in Gaza, ${ }^{58}$ which aggravated its blockade to deepen an ongoing humanitarian crisis. Turkey's October 2009 cancellation of Anatolian Eagle military exercises with Israel, which caused the United States and Italy to withdraw as well, invited speculation that Israeli authorities would no longer defend Turkey against U.S. congressional resolutions recognizing the Armenian genocide. ${ }^{59}$ As if to compound its vulnerability there, Ankara (marking growing Turco-Sudanese trade ties) hosted Sudan's leader Omar el-Bashir, convicted by the ICC of war crimes in the Darfur region. ${ }^{60}$ Obama's lobbying against another congressional Armenian genocide resolution in April 2010 seemed notably lackluster. ${ }^{61}$

Two more events brought Turco-Israeli ties to the breaking point in mid-2010, further threatening to constrict Obama's latitude in promoting Turkey's interests. First, the IDF's May 2010 storming of the Turkey-registered ship in a flotilla attempting to break the Gaza blockage and the killing of eight Turkish activists on board, as well as the detention of nearly 100 other passengers, were widely denounced and prompted calls for an investigation. The Obama administration's mediation to secure the detainees' release maintained some semblance of U.S. 
neutrality in the widening fissure between Turkey and Israel (although the United States did not join in Turkey's unrequited demand for an apology by Israel). ${ }^{62}$ Obama also felt chagrined by Turkey's objection to further UN sanctions on Iran over its nuclear program. For a host of reasons, including an expansion of trade ties with Iran that reached $\$ 10$ billion in 2008, the Turkish Prime Minister Erdogan-whose country signed a May 2010 agreement to allow Russia to build a new power plant near Sinop-joined the Brazilian president Lula da Silva in brokering a fuel swap along the lines of a jettisoned October 2009 agreement (except with Turkey, not Russia, becoming the repository of Iran's low-enriched uranium) ${ }^{63}$ Believing the deal would mollify Iran, rotating UNSC member Turkey voted against a fourth round of sanctions in June 2010, although it later tempered its view on Tehran's willingness to talk. ${ }^{64}$ Though Defense Secretary Robert Gates partially attributed Turkey's vote to the EU's failure to provide "an organic link to the West that Turkey sought," the U.S. delegate to the UN Susan Rice labeled Turkey and Brazil as international "outliers." ${ }^{5}$ UN sanctions nonetheless passed, and the Obama administration approved U.S. sanctions on Iran's oil products trade in July. ${ }^{66}$

\section{Conclusion}

Advocating a "model partnership" with Turkey, Obama was instead forced to grapple with a new recurrence of marital strife. These troubles are not rooted simply in the U.S. government's tendency to treat "Turkey as a function of Washington's big idea of the moment." ${ }^{\prime 67}$ They have also sprung up on the Turkish side, as the JDP government arguably consolidated an earlier trend of marshalling religious forces for political purposes to accelerate "dismantling the Republic's code of conduct in statecraft - in the name of populism." ${ }^{68}$ Yet it took the aforementioned diplomatic imbroglios to force the U.S. foreign policy establishment to pay closer scrutiny to the presumed secular democratic quality of Turkey's polity per se. By 2010 Obama was hearing increasingly pointed questions about Turkey's merit as a NATO ally and the need to reassess U.S. policy on Turkey. ${ }^{69}$ The assistant secretary of state Philip Gordon even intoned that Turkey needed to demonstrate its commitment to NATO, the European Union, and the United States. ${ }^{70}$ Thus, Obama-who made eloquent mention in Ankara of Turkey's selfinitiated path to democracy, after which time his administration relegated Turkey lower on its list of policy priorities-was goaded by events germinating in Turkish political and diplomatic trends to 
focus on the quality of a bilateral relationship that is often taken for granted while also being prone to crisis.

\section{Notes}

1. President Barack Obama, remarks to the Turkish Parliament, White House Office of the Press Secretary, April 6, 2009, www.whitehouse. gov/the-press-office/remarks-president-obama-turkish-parliament. (Accessed on February 16, 2011).

2. Ibid.

3. Ibid.

4. Mark R. Parris, "Common Values and Common Interests? The Bush Legacy in US-Turkish Relations," Insight Turkey 10, no. 4 (2008): 13. Indeed, although the Pew Research Center's 2009 polling showed only a slight rise in U.S. overall favorability ratings in Turkey (from a low of 9 percent in 2007 to 14 percent in 2009), 33 percent of surveyed Turks expressed confidence that Obama "will do the right thing," as opposed to 2 percent expressing similar confidence in Bush in 2008. See Pew Global Attitudes Project, Most Muslim Publics Not So Easily Moved: Confidence in Obama Lifts U.S. Image around the World, July 23, 2009, pp. 1-2.

5. Fusun Turkmen, "Turkish-American Relations: A Challenging Transition," Turkish Studies 10, no. I (2009): 122.

6. Jim Bodgener, "Armenian Dead Haunt Turkey's Relations with the US: A Congressional Resolution Striking at Deepseated National Sentiments," Financial Times, February 23, 1990, p. 3.

7. "President Barack Obama Holds a News Conference with Turkish President Abdullah Gul-News Conference," Financial Market Regulatory Wire, April 6, 2009.

8. Turkmen, "Turkish-American Relations," 111-112.

9. Charles P. Kindleberger, "Dominance and Leadership in the International Economy: Exploitation, Public Goods, and Free Rides," International Studies Quarterly 25, no. 2 (1981): 248.

10. U.S. Census Bureau, Statistical Abstract of the United States: 1994 (Washington, DC: GPO, 1994), 814.

11. Kenneth N. Waltz, Theory of International Politics (New York: Random House, 1979), 168-169.

12. Joseph C. Satterthwaite, "The Truman Doctrine: Turkey," Annals of the American Academy of Political and Social Science 401, America and the Middle East (1972): 79.

13. Barton J. Bernstein, "The Cuban Missile Crisis: Trading the Jupiters in Turkey?” Political Science Quarterly 95, no. 1 (1980): 99.

14. Bernstein, "Cuban Missile Crisis," 102.

15. Nur Bilge Criss, "A Short History of Anti-Americanism and Terrorism: The Turkish Case," Journal of American History 89, no. 2 (2002): 475. 
16. Charlotte Wolf, Garrison Community: A Study of an Overseas American Military Colony (Westport, CT: Greenwood Publishing Corporation, 1969), 57n9; and Criss, "Short History," 473.

17. Turkmen, "Turkish-American Relations," 112-113.

18. Criss, "Short History," 475.

19. Ahmet Davutoglu, "Turkey's Zero-Problems Foreign Policy," Foreign Policy, May 20, 2010, www.foreignpolicy.com/articles/2010/05/20 /turkeys_zero_problems_foreign_policy. (Accessed on February 16, 2011).

20. U.S. Census Bureau, Statistical Abstract of the United States: 1994, 814.

21. U.S. Census Bureau, Statistical Abstract of the United States: 1978 (Washington, DC: GPO, 1978), 871-873 (for 1975 figures); Statistical Abstract of the United States: 1979 (Washington, DC: GPO, 1979), 857-859.

22. Criss, "Short History," 473-476; Turkmen, "Turkish-American Relations," 112-113.

23. Criss, "Short History," 476-482.

24. Amy E. Schwartz, "Atta Turk: Ozal Looks West," New Republic (Washington, DC), April 15, 1991, pp. 19-21.

25. Turkmen, "Turkish-American Relations," 113.

26. Morton Abramowitz, "The Turkish Portfolio," American Interest 4, no. 3 (2009): 64.

27. Kenneth Katzman, "Iraq: Oil-for-Food Program, International Sanctions, and Illicit Trade," Congressional Research Service, February 28, 2003, pp. 1-2, 14.

28. Paul A. Williams, "Turkey's $\mathrm{H}_{2} \mathrm{O}$ Diplomacy in the Middle East," Security Dialogue 32, no. 1 (2001): 28-32.

29. Ziya Onis and Suhnaz Yilmaz, "Between Europeanization and EuroAsianism: Foreign Policy Activism in Turkey during the JDP Era," Turkish Studies 10, no. 1 (2009): 1.

30. Turkmen, "Turkish-American Relations," 113.

31. U.S. Census Bureau, Statistical Abstract of the United States: 1990 (Washington, DC: GPO, 1990), 806-807 (for 1980 and 1988 figures); U.S. Census Bureau, Statistical Abstract of the United States: 1994, 823826 (for 1992 figures); and U.S. Census Bureau, Statistical Abstract of the United States: 2001 (Washington, DC: GPO, 2001), 802-805 (for 2000 figures).

32. Chris Morris, "US Offers Turkey lbn in Quake Aid," Guardian (UK), November 16, 1999; and International Monetary Fund, “Turkey: Financial Position in the Fund as of December 31" (2000), www.imf. org/external/np/fin/tad/exfin2 aspx? memberkeyl=980\&datel Key=2 000-12-31. (Accessed on February 16, 2011).

33. Jan H. Kalicki, "U.S. Policy in the Caspian: Pipelines, Partnership and Prosperity," Middle East Policy 6, no. 2 (1998): 145-149. 
34. Kenneth Katzman, "Iran Sanctions," Congressional Research Service, June 23, 2010, www.fas.org/sgp/crs/mideast/RS20871.pdf. (Accessed on July 15, 2010).

35. Paul A. Williams and Ali Tekin, "The Iraq War, Turkey, and Renewed Caspian Energy Prospects," Middle East Journal 62, no. 3 (2008): 389-393.

36. Thomas Mattair, "The United States and Iran: Diplomacy, Sanctions and War," Middle East Policy 17, no. 2 (2010): 51.

37. Chris Nuttall, "Turkish Deals with Iran Risk US Rift," Guardian(UK), August 12, 1996.

38. Katzman, "Iran Sanctions," 5.

39. Juliet Eilperin and Stephen Mufson, "Hastert Withdraws 'Genocide' Resolution; Clinton Plea, Ties with Turkey Cited," Washington Post, October 20, 2000, p. A04.

40. Ziya Onis and Suhnaz Yilmaz, "The Turkey-EU-US Triangle in Perspective: Transformation or Continuity?" Middle East Journal 59, no. 2 (2005): 271-273. The European Parliament itself called on Turkey to recognize the events of 1915 as genocide. Brian Kenety, "Politics: EU Reference to 'Genocide' Angers Turkey," Inter Press Service, November 16, 2000.

41. Onis and Yilmaz, "The Turkey-EU-US Triangle," 273.

42. Cameron S. Brown, "Turkey in the Gulf Wars of 1991 and 2003," Turkish Studies 8, no. 1 (2007): 98-100.

43. Onis and Yilmaz, "Between Europeanization and Euro-Asianism," $12-13$.

44. Onis and Yilmaz, "The Turkey-EU-US Triangle," 276-277.

45. Turkmen, “Turkish-American Relations," 123-125.

46. Brown, "Turkey in the Gulf Wars," 101.

47. "US May Offer de Facto Recognition to Turkish Cypriots: Officials," Agence France Presse, April 29, 2004; and George Parker and Joshua Chaffin, "US Presses Case for Turkey's Accession to EU," Financial Times, June 27, 2004.

48. George Parker and Judy Dempsey, “EU Tells US to Stay out of Turkey's EU Bid," Financial Times, April 21, 2003.

49. Demetri Sevastopulo and Vincent Boland, "US Urges Turkey to Limit Iraq Incursion," Financial Times, February 28, 2008. The United States' favorability rating rose from 9 percent in 2007 to 12 percent in 2008, according to Pew Global Attitudes Project 2009, p. 1.

50. Deb Riechmann, "Bush Meets Turkish Leaders as They Grapple with Hostage Crisis," Associated Press, June 27, 2004; and U.S. State Department, "Remarks by President Obama at Student Roundtable in Turkey-Obama Committed to Rebuilding U.S. Relations with Muslim World," State Department Press Releases and Documents, April 7, 2009.

51. U.S. State Department, "Remarks by President Obama."

52. David Charter, "Leave Turkey's Bid to Join EU to Us, Sarkozy Warns Obama," Times (London), April 6, 2009. 
53. David O’Byrne, "Baku Snubs US-Turkey Summit," International Gas Report, April 13, 2009; and "Turkey Expects to Receive $€ 450 \mathrm{Mln}$ Annually from Nabucco," Hurriyet Daily News.com, July 11, 2009, www. hurriyet.com.tr/finance/12048098_p.asp. (Accessed on July 11, 2009).

54. Marc Champion, "Turkey, Armenia Break Ice," Wall Street Journal Europe, April 24, 2009, p. 1.

55. O’Bryne, "Baku Snubs"; Nadia Rodova, "Russian, Azeri Presidents Hope to Sign Azeri Gas Export Deal," Platts Commodity News, April 27, 2009.

56. Fulya Ozerkan, "Turkey Strikes Key Gas Deals with Azerbaijan," Hurriyet Daily News (Turkey), June 7, 2010, www.hurriyetdailynews. com/n.php?n=turkey-strikes-key-gas-deals-with-azerbaijan-2010 -06-07. (Accessed on June 7, 2010).

57. Turkmen, "Turkish-American Relations," 118-120.

58. Daniel Dombey and William Wallis, "US Struggles to Prevent Quartet Rift over Hamas," Financial Times, February 22, 2006, p. 10; Margaret Coker and Jay Solomon, "Israel Discusses Cease-Fire Amid New Attacks on Hamas," Wall Street Journal, January 2, 2009, p. Al; and Robert Tait, "International Reaction: Erdogan Risks Mediator Role," Guardian (UK), January 31, 2009.

59. Julian Borger, “Turkey Confirms It Barred Israel from Military Exercise Because of Gaza War," Guardian Unlimited (UK), October 13, 2009.

60. Nicholas Birch and Sarah Childress, “Turkey Says It Won’t Arrest Sudan President during Visit," Wall Street Journal Europe, November 6, 2009, p. 10.

61. Marc Champion, “Erdogan Calls Israel 'Threat' to Peace; Turkish Premier's Remarks Further Strain Countries' Alliance as Analysts Ponder Nation's Foreign-Policy Leanings," Wall Street Journal, April 8, 2010.

62. Gerald F. Seib, “U.S. Plays Therapist with Turkey, Israel," Wall Street Journal, June 4, 2010.

63. Sinan Ulgen, "Preventing the Proliferation of Weapons of Mass Destruction: What Role for Turkey?" Discussion Paper Series-2010/2 (Edam: Centre for Economics and Foreign Policy Studies, 2010), 12-15.

64. George Percovich, "Sanctions on Iran-The Least Bad Option," Carnegie Endowment for International Peace, June 28, 2010, http: // carnegie end ow ment.org/publications/index. cfm?fa=view\&id=41066. (Accessed on February 16, 2011); Marc Champion, "World News: Turkey Takes Iran to Task over Delay in Nuclear Talks," Wall Street Journal, June 30, 2010, p. Al3.

65. Daniel Dombey, Alex Barker, and Najmeh Bozorgmehr, "US Blames Europe as Turkey Opposes Sanctions," Financial Times, June 9, 2010.

66. Greg Bruno, "The Lengthening List of Iran Sanctions, Council on Foreign Relations: Backgrounder," July 28, 2010, www.cfr. 
org/publication/20258/lengthening_list_of_iran_sanctions.html. (Accessed on February 16, 2011).

67. Parris, "Common Values and Common Interests?" 6.

68. Nur Bilge Criss, "Dismantling Turkey: The Will of the People?” Turkish Studies 11, no. 1 (2010): 47.

69. Elliot Abrams, "A Turkey of a Policy: Obama Makes the Middle East an Even More Dangerous Place," Weekly Standard (USA), June 21, 2010, http://weeklystandard.com/print/articles/turkey-policy. (Accessed on February 16, 2011); Andrew C. McCarthy, "Turkey Turns," National Review, July 5, 2010, pp. 32-36; and Michael Rubin, "Turkey, from Ally to Enemy," Commentary, July-August 2010, pp. 81-86.

70. Delphine Strauss and David Gardner, "The Sentinel Swivels," Financial Times Asia Edition, July 21, 2010, p. 1. 